ing to the history of the State. Yet there is no doubt a rast wealth of material, that wonld afford enlightenment to the future and present investigator, at the homes of many. Perhaps, in many cases, undervalued in their historical relation by their owners, from their very commonness and familiarity. There is, no doubt, many an anecdote or fact carried about in the memory of old settlers, bearing upon important erents of State history, which some future historian would consider worth a journey across the State to learn. To the holders of the one class we would say, the State Historical Rooms are the appropriate places of deposit; and to the other, the pages of the AnNals are open and invite communications.

\title{
MY FIRST AND LAST VISIT TO THE STATE UNIVERSITY OF IOWA.
}

Among the institutions organized and fostered by the State, its University, the crowning fabric of its excellent school system, ranks second to none in importance.

After struggling through many difficulties, and experiencing many vicissitudes during its brief history, it has now reached a condition of usefulness very gratifying to all who take interest in its success.

Every year it is making its onward march and establishing successive increased educational facilities, until now it has taken rank, not only among the foremost of kindred institutions at the West, but is pressing close upon the venerable institutions of the older states.

- Ten years ago we made our first visit to it. It seemed then a wee, feeble thing, struggling faintly for life; adrancing with cautious and halting steps; reaching out supplicating hands for the patronage of the people.

At that time a corps of teachers were expending their energies upon two or three score of pupils from its immediate vicinity. Confined to a single building, with rooms just sufficient to accommodate the recitations of the few classes in attendance, and destitute of any but the most rudimentary apparatus. Afterward it was suspended for want of funds, and to give time and opportunity to its trustees to gather up its resources for a new trial.

The other day, during commencement week, we took occasion to "go through the University" again.

It now numbers its students by the half thousand, and receives its patronage from every county, and almost every neighborhood, in the commonwealth. 
It is now spread over three noble buildings, one containing a chapel of superior architectural finish, and with a capacity of seven hundred persons. Extensive and commodious philosophical rooms; with a chemical laboratory on a magnificent scale. Its library, hitherto of slow growth, is receiving a large increase to its number of volumes, and, under the liberal appropriation of the Legislature, it will soon be, in point of size and quality, of a character worthy a great state institution.

The shelves of the cabinet rooms are becoming peculiarly attractive to those who have a taste for such investigations or pursuits, and are receiving from year to year valuable accessions, and we learn that active efforts are being made to push the enlargement of this department, especially that of natural history, and it is expected within a few years to be able to secure a full representation of the natural history of the west.

One thing quite important to complete the appointments of the institution is not yet secured, to-wit : an Astronomical Observatory. And still further, to bring out the fullest measure of its benificence to the people of the state, Departments of Medicine, Law and Theology, are needful.

The gymnasium, hitherto a noticeable feature of the exercises to the casual visitor, is for the present suspended,-we trust, abolished. Up to a recent date the picturesque costume of the gymnasts, male and female, were conspictious on our streets, as the troops of students passed to and from the hall dedicated to that performance. Nor were they confined to the students. Many citizens, hoping for a quick return of strength to enfeebled systems, or a speedy access of vigor to the healthful, thronged the private classes, which were formed for their instruction and exercise. For a time physical training paid. It is rare now to see one of those gay, jaunty, and graceful costumes worn, and most sensible people, many of whom were of the number, are glad. The failnre to see any thing in the physique, or tone of physical action, of the members of its classes, superior to that of the students of the olden time; and the significant brief life of two of its three professors; and the failure of the third, has checked enthusiasm and sent people to the old practices for exercise. And we hope that we have seen the last of large assemblages of exhausted students in dusty halls, and the last of the jerking, bending, twisting, and unnamable contortions which make a part of the Dio Lewis system, and that greater faith may be placed in man- 
ly exercises out of doors, in God's free air, which every college student has from time immemorial found time and taken opportunity to secure.

The fewness of the graduating class, compared to the large number of students in attendance, is no doubt a noticeable fact to the visitor unacquainted with the peculiar organization of the classes. But this is readily and satisfactorily explained in the fact that the teachers of the University have thus far been compelled to first prepare their material for classes and then work it up; that is: to receive youths from the primary schools of the state and prepare them, in a separate department, to enter college classes. It is further explained, in the fact of the system adopted a few years ago by the trustees, and the then heads of departments, called the "elective system," which means, in short, that pupils may pursue only such branches of the course as they themselves choose, - the conferring of the degree, however, depending on proticiency in the whole course. Comparatively few adopt the whole course-hence, the few degrees conferred. It is time for such a system to pass away, supplanted by one that compels a thorough course to all as the condition of attendance. The present system may have been wise at the time of its adoption, when few youths could afford the time or had the means, or the preparatory instruction and education, to undertake a full course with success. But that day has passed, and an institution so finely endowed, so amply equipped with all the paraphanalia of science, should require breadth as well as thoroughness of scholarly acquirements, and discharge fully educated classes.

All in all, it is a noble institution, doing a great edncational work for the youth of the state, and meets a necessity which otherwise would leave thousands unaided in their efforts for a liberal edncation.

CORRECTIONS. - A typographical error occurs in giving the date of the birth of General Herron in the January number of THE ANsals. It should read 1837.

In the April number, in the sketch given of General Vandever, the following sentence occurs: "He received such education as only the public schools of that city afforded." This was intended to convey the fact of his not having the opportunities of the higher institutions of learning, but only the ordinary schools of the eity, which would be more properly denominated private schools, as it was before the day of the establishment of the system of public schools as now: understood. 
Copyright of Annals of Iowa is the property of State of Iowa, by \& through the State Historical Society of Iowa and its content may not be copied or emailed to multiple sites or posted to a listserv without the copyright holder's express written permission. However, users may print, download, or email articles for individual use. 